\title{
Analisis SWOT sebagai Upaya Peningkatan Keunggulan Kompetitif Usaha Mikro Kecil Menengah (UMKM) di Wilayah Jakarta Timur
}

\author{
${ }^{*}$ Rahmi1), Sholatia Dalimunthe ${ }^{2)}$, Dewi Susita ${ }^{3)}$ \\ ${ }^{1)}$ Program Studi S1 Manajemen, Fakultas Ekonomi, Universitas Negeri Jakarta \\ ${ }^{2)}$ Program Studi D3 Manajemen Pemasaran, Fakultas Ekonomi, Universitas Negeri Jakarta \\ ${ }^{3)}$ Program Studi S2 Magister Manajemen, Fakultas Ekonomi, Universitas Negeri Jakarta
}

Corresponden author: rahmi @unj.ac.id

Received : 1 September $2021 \quad$ Accepted : 29 September $2021 \quad$ Published: 30 September 2021

DOI: https://doi.org/10.37012/jpkmht.v3i2.698

\begin{abstract}
ABSTRAK
Pandemi Covid-19 berimbas ke segala bidang, termasuk Usaha Mikro Kecil Menengah (UMKM). Data menunjukkan hanya kurang dari 6\% UMKM yang mengalami pertumbuhan positif selama masa pandemi ini. Agar dapat bertahan dan memenangkan persaingan, pelaku UMKM harus melakukan berbagai strategi, salah satunya adalah menganalisis kondisi internal dan eksternal usaha. Tim Pengabdian kepada Masyarakat Fakultas Ekonomi Universitas Jakarta bekerja sama dengan Suku Dinas Koperasi, UMKM, dan Perdagangan Jakarta Timur mengadakan pelatihan analisis SWOT (Strength, Weakness, Opportunity, Threat) sebagai usaha evaluasi diri usaha UMKM agar pelaku UMKM dapat mengenali kekuatan, kelemahan, peluang, dan ancaman usahanya. Peserta pelatihan adalah pelaku UMKM binaan Suku Dinas Koperasi, UMKM, dan Perdagangan Jakarta Timur. Pelatihan dilakukan secara daring menggunakan aplikasi Zoom dengan memaparkan materi mengenai analisis SWOT berisi definisi analisis SWOT, tujuan dan manfaat pelaksanaan analisis, langkah-langkah pelaksanaan analisis, contoh penerapan analisis, serta sesi tanya jawab dengan peserta sekaligus konsultasi mengenai permasalahan yang dihadapi oleh usaha mereka. Setelah mengikuti pelatihan, peserta diharapkan mampu mengidentifikasi SWOT usaha mereka dan melakukan tindakan korektif, antisipatif, dan konstruktif bagi usahanya.
\end{abstract}

Kata Kunci: Analisis Internal, Analisis Eksternal, SWOT, UMKM.

\begin{abstract}
The Covid-19 pandemic has affected all fields, including Micro, Small, and Medium Enterprises (MSMEs). Data shows that only less than 6\% of MSMEs experienced growth during this pandemic. To survive and win the competition, MSME actors must carry out various strategies, one of which is analyzing the internal and external conditions of the business. The Community Service Team of the Faculty of Economics, Jakarta State University in collaboration with the East Jakarta Cooperative, MSME, and Trade Sub-Department held a SWOT (Strength, Weakness, Opportunity, Threat) analysis training as an evaluation of MSME self-business so that MSME actors could identify strengths, weaknesses, opportunities, and threats of their business. Participants were MSME actors assisted by the East Jakarta Cooperative, MSME, and Trade Sub-Department. The training was carried out online using the Zoom application by presenting material on SWOT analysis which contained the definition of SWOT analysis, the objectives and benefits, steps for carrying out the analysis, examples of implementation, as well as question and answer sessions with participants and consultation on the problems faced by their business. After attending the training, participants were expected to be able to identify the SWOT and take corrective, anticipatory, and constructive actions.
\end{abstract}

Keywords: Internal Analysis, External Analysis, SWOT, MSMEs. 


\section{PENDAHULUAN}

Usaha Mikro, Kecil, dan Menengah (UMKM) memegang peranan penting di sektor ekonomi Indonesia. Pertumbuhan UMKM di Indonesia yang sedang pesat-pesatnya terhambat situasi pandemi Covid-19. Berdasarkan survei organisasi buruh internasional (ILO) pada April 2020 hampir 70\% UMKM berhenti produksi, 63\% meminta karyawannya cuti berbayar atau tidak berbayar, dan $90 \%$ mengalami masalah arus kas (Kussudyarsana, 2021). Selain itu, menurut Katadata Insight Center (KIC), hanya sebanyak 5,9\% UMKM yang mengalami pertumbuhan positif, sedangkan mayoritas UMKM $(82,9 \%)$ merasakan dampak negatif dari pandemi ini (https://katadata.co.id/, 2020). Lebih lanjut, data yang diperoleh dari hasil survey terhadap 206 pelaku UMKM di Jabodetabok pada bulan Juni 2020 ini menyebutkan bahwa hanya sebanyak 3,8\% UMKM yang mengalami peningkatan omzet, sementara 63,9\% UMKM bahkan mengalami penurunan omzet usaha hingga lebih dari $30 \%$. Kondisi ini menyebabkan semakin ketatnya persaingan.

UMKM dituntut untuk mampu bersaing di tengah pandemi meskipun sulit. Padahal sebelum pandemi saja UMKM masih mengalami kesulitan dalam bersaing disebabkan beberapa permasalahan. Salah satu permasalahan adalah UMKM tidak menguasai pasar yang disebabkan oleh cara pandang UMKM yang hanya menjadikan usaha sebagai kegiatan dalam memenuhi kebutuhan sehari-hari sehingga pengelolaan manajerial UMKM tidak berjalan baik. Selain itu, permasalahan UMKM lainnya adalah kurangnya inovasi. Hal ini pula yang menyebabkan UMKM tidak tahu cara membesarkan bisnisnya. UMKM tidak mengerti target pasar mereka sehingga produk yang dijual tidak sesuai dengan selera konsumen. Di lain sisi, UMKM hanya mengetahui memproduksi barang akan tetapi tidak tahu harus menjual kemana. Banyak UMKM yang hanya terfokus pada produksi tanpa memikirkan ekspansi bisnisnya (Ibnuismail, 2020).

Lebih jauh, banyak UMKM yang tidak mengetahui bahwa produk mereka memiliki keunggulan yang diminati pasar global (Al Faqir, 2020). Keunggulan inilah yang harusnya dikembangkan oleh UMKM. Apabila keunggulan ini memiliki nilai yang berbeda dan unik dibanding pesaing maka nantinya akan menjadi keunggulan kompetitif. Ketika UMKM memiliki keunggulan kompetitifnya berarti UMKM mampu bersaing dengan banyaknya pesaing. Akan tetapi, banyak UMKM yang hanya terfokus pada produksi barang tanpa tahu bagaimana keadaan lingkungannya atau target pasarnya, padahal mengetahui lingkungan usaha merupakan langkah awal dalam mencapai keunggulan kompetitif suatu usaha. Lingkungan usaha tersebut meliputi lingkungan internal dan eksternal usaha. UMKM yang mengetahui lingkungannya akan lebih 
mudah untuk berinovasi dan mencari solusi dalam permasalahan yang terjadi di UMKM. Oleh karena itu, diperlukan kemampuan pelaku UMKM dalam menganalisis lingkungan internal dan eksternalnya.

Berdasarkan latar belakang tersebut, terdapat beberapa masalah pada mitra atau pelaku UMKM khususnya binaan Suku Dinas Koperasi, UMKM, dan Perdagangan Jakarta Timur yaitu banyak pelaku usaha yang tidak mengetahui bagaimana menganalisis lingkungan internal dan eksternalnya serta bagaimana cara mengatasi kendala yang dihadapi berdasarkan hasil analisis tersebut. Untuk menyelesaikan permasalahan ini, tim Pengabdian pada Masyarakat Fakultas Ekonomi Universitas Negeri Jakarta mencoba memberikan pelatihan analisis SWOT kepada pelaku UMKM Jakarta Timur. Pelaku UMKM akan dijelaskan tentang definisi keunggulan kompetitif dan definisi SWOT beserta fungsinya.

Keunggulan kompetitif merupakan keunggulan yang dimiliki perusahaan dibandingkan pesaingnya. Perusahaan yang memiliki keunggulan kompetitif memiliki kinerja yang lebih baik dibandingkan pesaingnya. Keunggulan kompetitif dapat diciptakan ketika sebuah perusahaan memiliki kompetensi yang berbeda dari pesaingnya. Kompetensi tersebut didapat dari pengelolaan sumber daya yang dimiliki oleh perusahaan. Ketika perusahaan memiliki kompetensi tersebut, terdapat beberapa keuntungan yaitu pesaing kesulitan untuk meniru kompentensi perusahaan, kompetensi tersebut sesuai dengan kebutuhan pasar, dan kompetensi dapat menjadi alat dalam pembelajaran dan prinsip kerja dalam menyelesaikan masalah. Perusahaan dapat memilih 2 strategi untuk mendapatkan competitive advantage yaitu, (1) cost leadership strategy yaitu strategi yang menekankan pada biaya rendah dari pesaing dan (2) strategi diferensiasi yaitu strategi yang menekankan pada keunikan produk/jasa yang dihasilkan (Witcher, 2020).

Untuk mengetahui lingkungan bisnis, perusahaan harus menganalisa lingkungan internal dan eksternal. Lingkungan internal adalah kemampuan dan kelemahan perusahaan. Kemampuan perusahaan adalah keunggulan yang dimiliki perusahaan baik dari segi produk, pemasaran, jumlah outlet, atau sumber daya manusia. Kelemahan perusahaan adalah ketidakmampuan perusahaan dalam fungsionalnya, misalnya ketidakmampuan pemasaran.

Lingkungan eksternal perusahaan merupakan peluang dan ancaman. Peluang merupakan kondisi menguntungkan yang dapat membuat perusahaan menjadi berkembang. Sedangkan ancaman adalah kondisi merugikan yg dapat membuat perusahaan mengalami penurunan atau kebangkrutan.

Analisa lingkungan internal dan ekternal memerlukan sebuah framework. Framework tersebut adalah analisis SWOT, yang berarti Strength (Kekuatan), Weakness (Kelemahan), Opportunity 
(Peluang), dan Threat (Ancaman). Ide besar dari SWOT adalah perusahaan mampu membangun kekuatan, mengatasi kelemahan, mengambil keuntungan dari peluang yang ada, melindungi perusahaan dari ancaman (Dess, McNamara, Eisner, \& Lee, 2019). Terdapat beberapa tahapan dalam SWOT, yaitu memutuskan tujuan dilakukan analisis SWOT, melakukan penelitian tentang bisnis, industri, dan pasar, membuat daftar kekuatan, membuat daftar kelemahan, membuat potensi peluang untuk bisnis, membuat potensi ancaman dalam bisnis, serta yang terakhir adalah menyusun prioritas dalam SWOT.

\section{METODE PELAKSANAAN}

Berdasarkan solusi permasalahan yang telah dijelaskan, maka perlu dilakukannya pelatihan analisis SWOT untuk pelaku UMKM di Jakarta Timur. Pelaksanaan kegiatan pelatihan UMKM ini akan dilakukan dalam beberapa tahap. Pada tahap persiapan, tim melakukan hal-hal berikut:

1. Analisis Kebutuhan

Tahap ini merupakan tahap identifikasi permasalahan pada mitra. Dalam tahap ini pihak pengusul mengadakan diskusi dengan mitra yaitu Suku Dinas Koperasi, UMKM dan Perdagangan Jakarta Timur untuk mengetahui kebutuhan pelaku usaha di Jakarta Timur.

2. Penjadwalan waktu pelaksanaan pelatihan dan durasi pelaksanan kegiatan

Tahap ini merupakan tahap koordinasi dengan mitra mengenai tanggal dan durasi kegiatan dilaksanakan. Pada tahap ini juga akan melakukan pemetaan peserta.

3. Persiapan materi

Tahap ini terkait dengan persiapan materi yg akan diberikan beserta media apa yang dibutuhkan dalam memberi pelatihan.

Kegiatan pengabdian pada masyarakat dengan tema Pelatihan Analisis SWOT dalam Upaya Meningkatkan Keunggulan Kompetitif UMKM di Wilayah Jakarta Timur ini diselenggarakan pada hari Kamis, 12 Agustus 2021 secara virtual melalui aplikasi Zoom. Kegiatan mengalami kemunduran dari rencana waktu pelaksanaan dikarenakan kondisi pandemik wabah Covid-19 yang juga menyebabkan salah satu anggota tim pengabdian pada masyarakat terjangkit wabah Corona sehingga harus menunggu hingga selesai masa pemulihan. Kegiatan dilaksanakan secara tatap maya karena di Jakarta masih diberlakukan Pemberlakuan Pembatasan Kegiatan Masyarakat (PPKM) dari pemerintah yang bertujuan untuk menekan penularan penyakit Corona.

Tim pelaksana kegiatan Pengabdian pada Masyarakat FE UNJ bekerja sama dengan Suku 
Dinas Koperasi, UMKM dan Perdagangan Jakarta Timur untuk menyebarkan pamflet elektronik kepadan kelompok UMKM binaannya yang bertujuan untuk menyebarkan informasi mengenai kegiatan serta menjaring peserta. Peserta dibatasi sebanyak sekitar 100 orang untuk menjaga keefektivitasan kegiatan dan target ini terpenuhi. Peserta yang telah mendaftar dikumpulkan ke dalam satu grup WhatsApp untuk memudahkan komunikasi dan koordinasi.

\section{HASIL DAN PEMBAHASAN}

Pelaku UMKM yang menjadi peserta berasal dari beragam jenis usaha namun sebagian besar didominasi oleh usaha makanan dan minuman, yaitu sebanyak hampir $75 \%$. Sisanya bergerak di bidang pakaian/fashion sebanyak sekitar 5\%, kerajinan tangan (craft) 4\%, dan sisanya tersebar di kecantikan, toko kelontong, buku, reseller, dan lainnya. Ditinjau dari lama tingkat pendidikan, dari 105 peserta yang mengisi daftar kehadiran, peserta didominasi oleh lulusan SMA/SMK/sederajat sebanyak 41 orang, diikuti oleh S1/D4 sejumlah 34 orang, D3 sebanyak 20 orang, SMP/sederajat 4 orang, S2 3 orang, SD 2 orang dan sisanya D1 1 orang.

Jika dilihat dari omzet usaha, mayoritas peserta sebanyak 98 orang memiliki omzet usaha di bawah 50 juta rupiah per bulan, 5 orang memiliki omzet usaha 51-100 juta rupiah per bulan, dan terakhir 2 orang memiliki omzet usaha 100-300 juta rupiah per bulan. Dapat disimpulkan bahwa kebanyakan usaha yang digeluti pelaku UMKM berskala mikro.

Hampir $85 \%$ peserta atau sebanyak 89 orang mengaku mengetahui tentang analisis SWOT dan 75 orang $(71 \%)$ sudah pernah mengikuti pelatihan analisis SWOT. Meski demikian, ketika diminta untuk mengidentifikasi kekuatan, kelemahan, peluang, dan ancaman bagi usahanya, masih banyak peserta yang belum bisa mengidentifikasi SWOT usaha masing-masing. Sebagian juga masih belum bisa membedakan antara strength dan opportunity, serta weakness dan threat. Hal ini terlihat dari jawaban pre-test dari para peserta yang diberikan sebelum kegiatan dilaksanakan.

Narasumber untuk materi analisis SWOT adalah Rahmi, salah seorang dosen pada Fakultas Ekonomi Universitas Negeri Jakarta. Rahmi mengawali paparannya dengan penjelasan mengenai definisi analisis SWOT. SWOT merupakan analisis lingkungan yang terdiri dari lingkungan internal (strength dan weakness) serta lingkungan eksternal (opportunity dan threat). Beberapa tujuan dilakukannya analisis ini antara lain sebagai arahan ataupun rekomendasi untuk mempertahankan kekuatan dan untuk menambah keuntungan dari segi peluang yang ada, alat untuk meminimalisasi kelemahan yang terdapat dalam suatu perusahaan atau organisasi serta menekan dampak ancaman yang timbul dan harus dihadapi, menyiapkan 
perusahaan untuk siap dalam menghadapi permasalahan yang terjadi, menganalisis prospek perusahaan, serta menyiapkan untuk menghadapi adanya kemungkinan perencanaan pengembangan di dalam perusahaan.

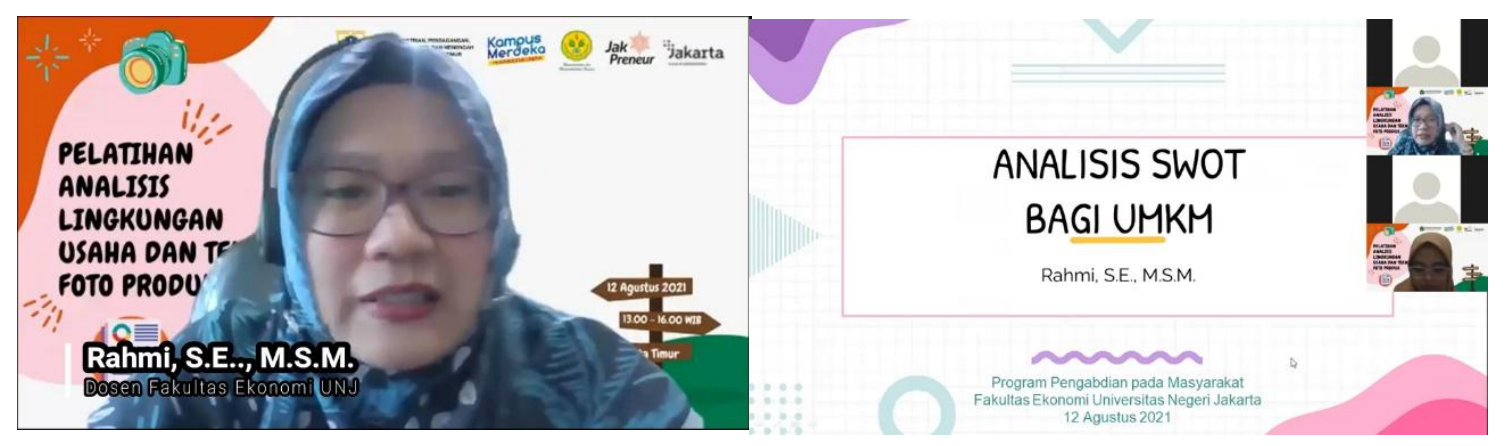

Gambar 1. Pemberian Materi Analisis SWOT

Selanjutnya, Rahmi menjelaskan langkah-langkah untuk menyusun analisis SWOT. Pada identifikasi kekuatan, pelaku usaha harus menemukan hal apa yang dilakukan secara baik oleh usahanya. Sebaliknya pada identifikasi kelemahan, pelaku usaha menggali hal apa saja yang masih menjadi kekurangan usaha dan perlu diperbaiki. Selanjutnya, peluang adalah kesempatan yang berasal dari lingkungan yang dapat mendukung keberlanjutan usaha. Yang terakhir adalah ancaman, yaitu kesulitan apa yang berasal dari luar perusahaan yang dapat menjadi hambatan bagi perusahaan.
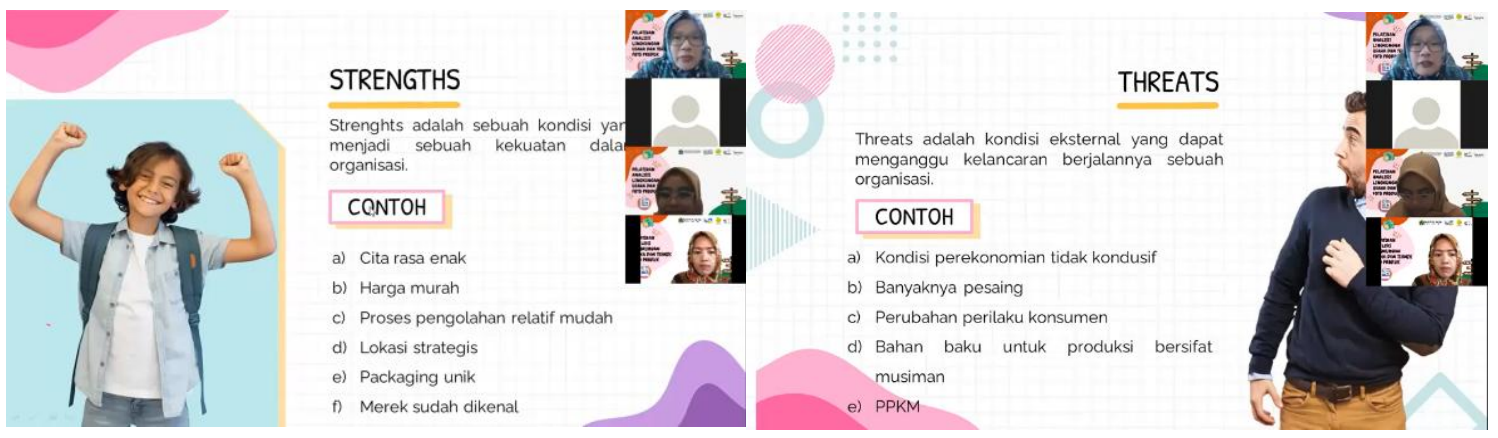

Gambar 2. Contoh Identifikasi Strengths dan Threats

Setelah identifikasi dilakukan, maka disusunlah poin-poin tersebut ke dalam sebuah matriks SWOT. Dari sini, dapat ditentukan strategi yang sesuai dengan strength-opportunity (S-O), weakness-opportunity (W-O), strength-threat (S-T), weakness-threat (W-T). Rahmi juga memberikan contoh-contoh yang sesuai dengan materi yang disampaikan untuk mempermudah pemahaman peserta mengenai analisis SWOT. 


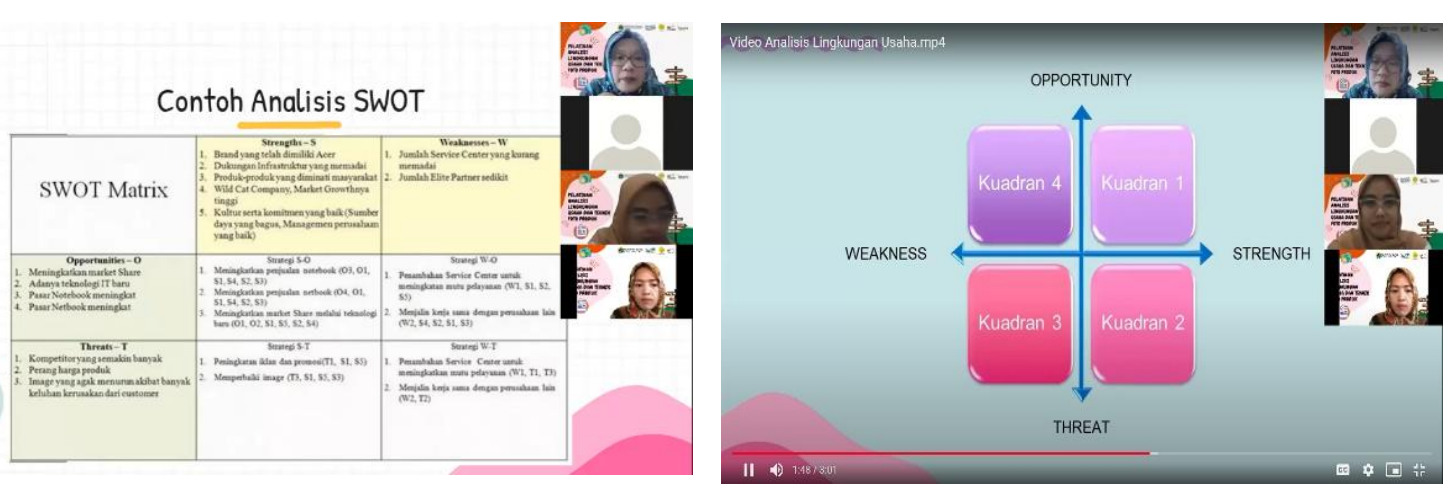

Gambar 3. Contoh Aplikasi Analisis SWOT

Sesi tanya jawab dilakukan seusai pemaparan materi. Di sini, Rahmi menyarankan untuk membuat usaha yang unik, menciptakan produk yang sering dikonsumsi oleh masyarakat, usaha dilakukan secara konsisten, serta selalu berinovasi. Menjadi reseller produk dapat menjadi solusi di masa pandemi yang menyulitkan pendanaan pada usaha.

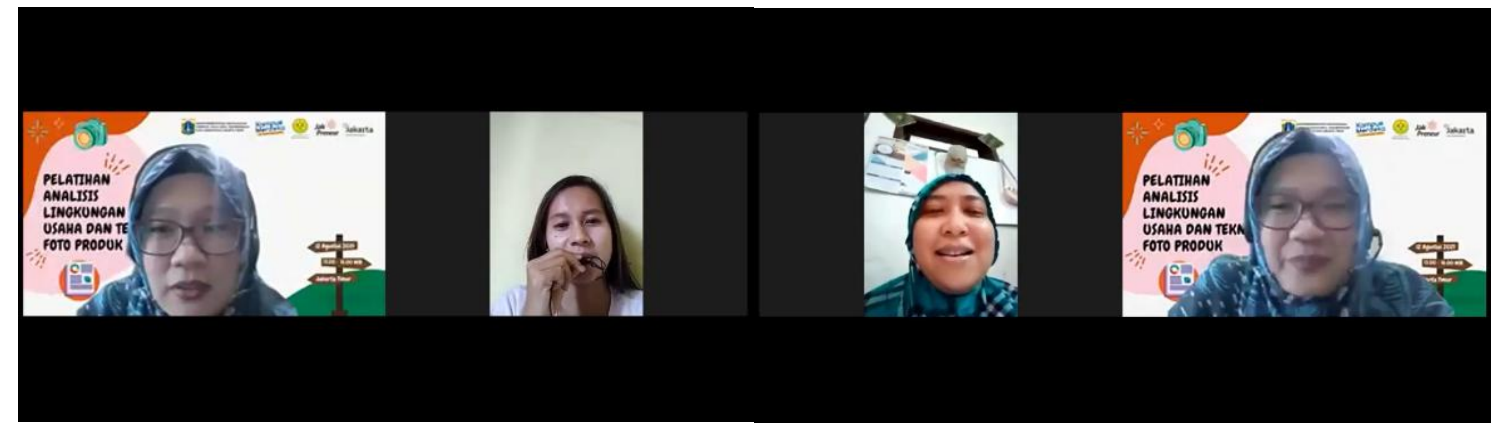

Gambar 4. Sesi Tanya Jawab

Setelah diberikan pelatihan, peserta mulai dapat mengidentifikasi SWOT usaha mereka. Ini terlihat dari jawaban post-test yang diajukan setelah acara dilaksanakan. Sebagian peserta berhasil menemukan kekuatan seperti bahan baku premium, produk yang dijual unik, tersertifikasi halal, harga kompetitif, tidak ada pesaing di wilayah usaha, kemasan yang menarik, cita rasa produk yang enak, dan jaringan kerja sama yang baik. Untuk kelemahan, contoh jawaban yang diberikan peserta adalah proses pengerjaan yang rumit, rasa dan tekstur produk mudah berubah, pemasok bahan baku terbatas, SDM yang kurang mumpuni, modal yang terbatas, kurangnya promosi, dan tampilan produk yang kurang memikat.

Pada sisi peluang, jawaban yang diberikan oleh peserta misalnya masih luasnya pasar, produk yang dihasilkan merupakan kebutuhan masyarakat di masa pandemi, gaya hidup masyarakat yang mulai sadar untuk menjaga kesehatan, serta adanya program bantuan dari pemerintah. Sementara pada sisi ancaman, peserta menjawab persaingan usaha yang kuat, situasi pandemi dan PPKM, daya beli masyarakat menurun, produk mudah ditiru pesaing, dan perkembangan teknologi yang cepat yang menyebabkan pelaku usaha harus terus menerus memperbarui pengetahuannya. 


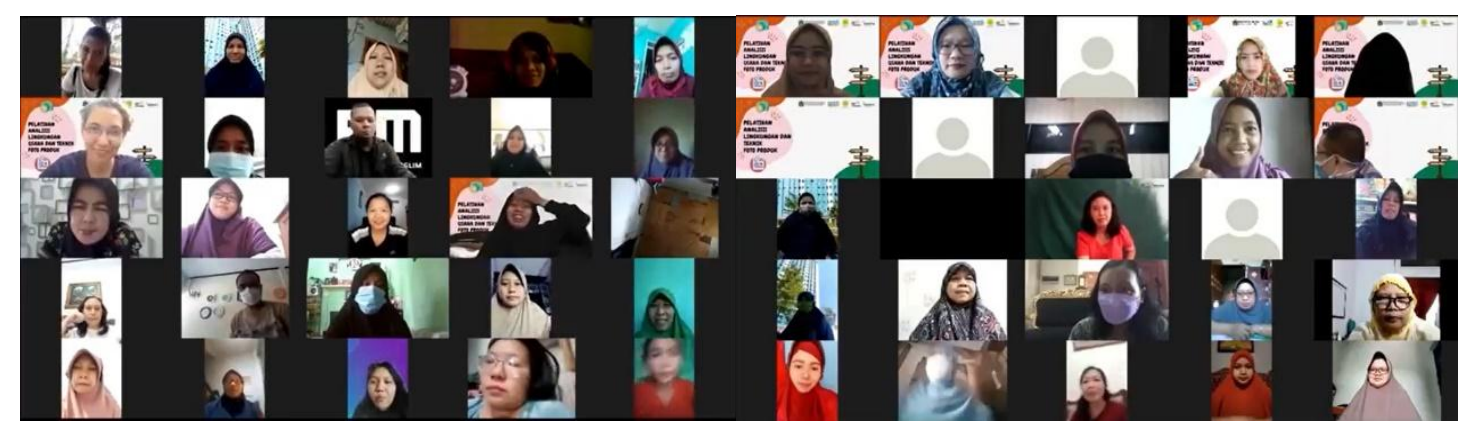

Gambar 5. Dokumentasi Peserta

\section{SIMPULAN DAN REKOMENDASI}

Analisis SWOT menjadi salah satu pilihan cara untuk menganalisis usaha yang dapat dilakukan oleh pelaku UMKM dalam mengenali kekuatan, kelemahan, peluang, dan ancaman usaha mereka untk menciptakan keunggulan kompetitif. Namun demikian, alat analisis ini masih belum banyak dimanfaatkan oleh pelaku UMKM. Kurangnya pemahaman mengenai konsep serta langkah-langkah analisis yang harus dilakukan merupakan salah satu alasan penghambat pelaksanaan tersebut. Hal ini dapat diatasi dengan melakukan edukasi terhadap pelaku usaha. Kegiatan pengabdian pada masyarakat ini menjadi ajang edukasi bagi pelaku UMKM di wilayah Jakarta Timur dalam pemanfaatan analisis lingkungan internal dan eksternal dalam analisis SWOT untuk menciptakan keunggulan kompetitif yang mendukung usahanya sehingga dapat memenangkan persaingan di pasar. Narasumber menyampaikan definisi, manfaat, langkah-langkah analisis, serta contoh penggunaannya dalam analisis usaha. Dengan kemampuan identifikasi SWOT, diharapkan pelaku usaha dapat menemukan keunggulan kompetitif usahanya, sehingga usaha tersebut dapat berkelanjutan dan menguntungkan.

Antusiasme peserta cukup tinggi dilihat dari jumlah peserta yang mendaftar untuk kegiatan serta interaksi yang berlangsung baik di dalam grup WhatsApp maupun ketika acara berlangsung. Mereka juga berharap dapat dilaksanakan kegiatan-kegiatan serupa di masa yang akan datang untuk mendukung kegiatan UMKM mereka. 


\section{REFERENSI}

1. Al Faqir, A. (2020, September 17). Retrieved from www.merdeka.com: https://www.merdeka.com/uang/menkop-teten-sebut-persaingan-usaha-di-sektorumkm-tinggi-saat-pandemi.html

2. Dess, G. G., McNamara, G., Eisner, A. B., \& Lee, S.-H. (2019). Strategic management : text \& cases. New York: McGraw-Hill Education.

3. https://katadata.co.id/. (2020). Retrieved from https://katadata.co.id/umkm

4. Ibnuismail. (2020, September 21). Retrieved from www.accurate.id: https://accurate.id/bisnis-ukm/7-masalah-yang-terjadi-pada-ukm-dan-tipsmengatasinya/

5. Kussudyarsana. (2021, August 6). Retrieved from www.radarsolo.jawapos.com: https://radarsolo.jawapos.com/pendidikan/06/08/2021/inovasi-dan-solusi-umkm-diera-pandemi-covid-19/

6. Witcher, B. (2020). Absolute Essentials of Strategic Management. Routledge. 